\title{
Miscellany
}

\section{Scottish Division Annual Awards - Winners 1997}

The Dista Audit Award was won by Dr P. Shajahan and Dr J. Cavanagh, and the McHarg Essay Prize by Dr R. Clafferty. Both papers were presented at the Scottish Division Summer Meeting in May. Three Lundbeck Medical Student Prizes were awarded to A. Kristina Sygel (Glasgow), Gillian Potter and Sohail Khan (both Edinburgh).

\section{Job-share register for psychiatrists - UK and Republic of Ireland}

The job-share register for psychiatrists in the UK and Eire is open to psychiatrists of all grades and is administered by the Women in Psychiatry Special Interest Group (WIPSIG) of the Royal College of Psychiatrists. Anyone wishing to register to find a job-share partner should contact Dr Louise Howard, c/o Sue Duncan at the Royal College of Psychiatrists, 17 Belgrave Square, London SW1X 8GP for a registration form. Completed forms will be processed and kept in confidence by WIPSIG.

\section{Depersonalisation Research Unit at the Institute of Psychiatry}

The Institute of Psychiatry in London has recently set up a new unit which will carry out research into the nature of the depersonalisation, using techniques such as brain imaging. The Unit is externally funded and will be run by Professor Anthony David and Dr Mary Phillips. The Unit aims to assess patients with primary depersonalisation and also to develop treatment regimens for this distressing condition. If you have contact with patients with primary depersonalisation and would like to refer them for an assessment, please contact Professor Anthony S. David/Dr Mary Philips, Depersonalisation Research Unit, Section of Neuropsychiatry, Dept. of Psychological Medicine, Institute of Psychiatry, London SE5 8AF (Telephone: 01719193138 / Fax: 0171740 5301; e-mail: spjuasd@iop.bpmf. ac.uk or spmamlp@iop.bpmf.ac.uk

\section{New publications}

\section{Workplace mental health and stress}

A new resource pack to help train bosses to manage mental health and stress in the workplace was recently launched by Angela Eagle, the minister with responsibility for health and safety. Produced by Cranfield School of Management, on behalf of the Government's Inter-Agency Group on Mental Health in the Workplace, the pack offers guidance on how mental well-being issues at work can and should be addressed. The pack is available for £25 from HSE Books, P.O. Box 1999, Sudbury, Suffolk CO10 6FS (Telephone: 01787881 165; Fax: 01787313 995).

New from the BMJ Publishing Group EvidenceBased Mental Health is a new quarterly journal designed to meet the needs of mental health specialists worldwide, including clinicians of all disciplines, managers and policy-makers. The Editors are John Geddes, Shirley Reynolds, David Streiner and Peter Szatmari. Worldwide subscription for Society Members (including Members of the Royal Colleges of Psychiatry, the Royal College of Nursing and the Psychological Society) is £45 (USA only \$72). Further information/orders: BMJ Publishing Group, P.O. Box 299, London WC1H 9TD (Telephone: +44 (0) 171383 6270; Fax: +44 (0) 1713836402 ; e-mail: bmjsubs@dial.pipex.com).

The Child and Adolescent Psychiatry Faculty has produced revised guidance on the management of young people up to the age of 16 who deliberately harm themselves. A summary will appear in the next issue of the Bulletin. Copies of the Report Managing Deliberate Self-Harm in Young People (Council Report CR64) are available for $£ 5$ from the Book Sales Office at the Royal College of Psychiatrists (Telephone: 0171 2352351 ext. 146).

Going to Out-Patients, by Sheila Hollins, Jane Bernal and Matthew Gregory, and Going Into Hospital, by Sheila Hollins, Angie Avis and Samantha Cheverton, are two new titles in the Books Beyond Words series. Both publications are available for $£ 10$ each from the Book Sales Office at the College. 